\title{
IMPLEMENTASI KEBIJAKAN “JOGO TONGGO" DI KECAMATAN SIMO KABUPATEN BOYOLALI PROVINSI JAWA TENGAH
}

\author{
Oleh \\ Samsul Arifin ${ }^{1}$, Diyana Nur Qoimah ${ }^{2}$ \\ ${ }^{1)}$ Institut Pemerintahan Dalam Negeri \\ samsularifin11112@gmail.com \\ ${ }^{2)}$ Dinas Kesehatan Kab. Boyolali
}

\begin{abstract}
THE IMPLEMENTATION OF THE "JOGO TONGGO" POLICY IN SIMO SUBDISTRICT BOYOLALI REGENCY CENTRAL JAVA PROVINCE
\end{abstract}

\begin{abstract}
$T$
The Jogo Tonggo policy is a policy issued by the Governor of Central Java to overcome the impact of the Covid-19 outbreak. This policy is implemented based on the local wisdom of the community, especially the people of Central Java, namely mutual cooperation. The implementation of this policy is carried out at the level of the community unit ( $R W$ ) by creating a Covid-19 task force called the Jogo Tonggo Task Force. This study aims to determine the implementation of the Jogo Tonggo Policy in Simo subdistrict, Boyolali Regency, Central Java Province and analyze the supporting and inhibiting factors as well as the efforts made by policy implementers to overcome the inhibiting factors for the implementation of this Jogo Tonggo Policy. In the preparation of this report, the authors used descriptive qualitative research methods with an inductive approach. The techniques used in data collection of this study were interviews, observations, documentations and triangulations. To analyze the data, the author uses data reduction, data presentation, and conclusion. The results of the research conducted show that the implementation of the Jogo Tonggo Policy in Simo sub district which is analyzed using the Edward III implementation theory which consists of 4 (four) dimensions, namely communication, resource, disposition and bureaucratic structures have been running well in accordance with existing guidelines. Supporting factors of this policy are the culture of mutual cooperation, concern and togetherness that are still strong in the community, and clear coordination among those policy implementers. However, there are still inhibiting factors such as citizens who do not understand the Jogo Tonggo Policy, and low public awareness of health protocols. Efforts made by policy implementers to overcome these obstacles are to conduct socialization, provide examples to the community, and hold contact tracking.
\end{abstract}

Keywords: implementation, policy, Jogo Tonggo

\section{Abstrak}

$\mathrm{K}^{2}$ ebijakan Jogo Tonggo merupakan sebuah kebijakan yang dikeluarkan oleh Gubernur Jawa Tengah untuk mengatasi dampak terjadinya Covid-19. Kebijakan ini dilaksanakan berbasis kearifan lokal masyarakat, khususnya masyarakat Jawa Tengah yaitu gotong royong. Pelaksanaan kebijakan ini dilakukan di tingkat rukun warga (RW) dengan membuat Satgas Covid-19 yang bernaman Satgas Jogo Tonggo. Tujuan dilaksanakan penelitian ini adalah untuk 
mengetahui implementasi kebijakan Jogo Tonggo di Kecamatan Simo Kabupaten Boyolali Provinsi Jawa Tengah, faktor pendukung dan penghambat, serta upaya yang dilakukan untuk mengatasi faktor penghambat tersebut. Pada pelaksanaan penelitian ini penulis menggunakan metode penelitian kualitatif deskriptif dengan pendekatan induktif. Teknik yang digunakan dalam pengumpulan data pada penelitian ini adalah wawancara, observasi, dokumentasi dan triangulasi. Untuk melakukan analisis data penulis menggunakan cara reduksi data, penyajian data, dan simpulan. Hasil penelitian yang dilakukan menunjukkan bahwa Implementasi Kebijakan Jogo Tonggo di Kecamatan Simo yang dianalisis dengan menggunakan teori implementasi Edward III yang terdiri dari empat dimensi yaitu komunikasi, sumber daya, disposisi dan struktur birokrasi sudah berjalan baik sesuai dengan pedoman yang ada. Faktor pendukung kebijakan ini adalah budaya gotong royong, kepedulian dan kebersamaan yang masih kental di masyarakat, serta koordinasi yang jelas antar pelaksana kebijakan ini. Namun, masih terdapat faktor penghambat seperti adanya warga yang belum memahami Kebijakan Jogo Tonggo, dan kesadaran masyarakat terhadap protokol kesehatan masih rendah. Upaya yang dilakukan para pelaksana kebijakan untuk mengatasi hambatan tersebut adalah melakukan sosialisasi, memberikan contoh kepada masyarakat, dan melakukan contact tracking.

Kata kunci: implementasi, kebijakan, Jogo Tonggo

\section{PENDAHULUAN}

$\mathrm{I}^{2}$

ndonesia saat ini tengah menghadapi pandemi corona virus disease 2019 (Covid-19). Virus ini merupakan virus yang dapat menginspeksi hewan dan manusia, serta dapat menular hanya dengan menyentuh barang yang sudah terkena droplet (percikan air liur) dari orang yang telah terinfeksi sebelumnya. Oleh karena itu, virus ini sangat mudah menular dan menyebar yang akibatnya virus ini menjadi pandemi yang menyerang di hampir seluruh negara di dunia. Pada 11 Maret 2020 World Health Organization (WHO) menetapkan wabah ini sebagai pandemi global. Dampak yang disebabkan oleh adanya virus ini sangat masif tidak hanya di bidang kesehatan namun disuruh aspek seperti pendidikan, ekonomi. Bahkan hingga ke keamanan juga terkena dampaknya.

Virus corona pertama kali ditemukan pada saat ditemukan kasus pneumonia di Kota Wuhan, Provinsi Hubei, China, pada 31 Desember 2019. Hari ke hari semakin banyak yang terkena virus ini, jumlahnya bisa puluhan hingga ratusan hingga menyebar ke seluruh dunia. Indonesia sendiri mengumumkan kasus pertamanya pada 17 maret 2020. Akibat terjadinya pandemi ini pemerintah menetapkan Keputusan Presiden (Keppres) No. 11 Tahun 2020 tentang Penetapan Kedaruratan Kesehatan Masyarakat corona virus disease 2019 (Covid-19) yang menyebutkan bahwa wajib dilakukan upaya penanggulangan sesuai dengan peraturan perundang-undangan.

Berdasarkan aturan tersebut menurut Elnizar (2020) yang dikutip dalam Erisandi Arditama dan Puji Lestari dalam artikelnya yang dimuat di Jurnal Politik dan Kewarganegaraan, Fakultas Ilmu Sosial Universitas Negeri Semarang, berjudul Jogo Tonggo: Membangkitkan Kesadaran Dan Ketaatan Warga Berbasis Kearifan Lokal pada Masa Pandemi Covid-19 di Jawa Tengah:

"Keadaan darurat adalah darurat bencana yang dianggap mengancam dan mengganggu kehidupan masyarakat disebabkan oleh alam, non-alam yang membahayakan, mengakibatkan korban, kerusakan, dan dampak psikologis".

Pemerintah membuat berbagai kebijakan yang berskala nasional sebagai upaya mengurangi dampak adanya pandemi Covid-19 bagi masyarakat. Beberapa kebijakan di antaranya adalah kelonggaran kredit subsidi listrik, pembatasan sosial yang saat ini dinamakan pemberlakuan pembatasan kegiatan masyarakat (PPKM), 
kelonggaran membayar kredit, bantuan sosial tunai, hingga pembelajaran jarak jauh yang masih diterapkan sampai saat ini. Pembuatan kebijakan yang telah dilakukan oleh pemerintah ternyata masih belum dapat mengatasi dampak pandemi ini, sehingga pada akhirnya Covid-19 ditetapkan sebagai bencana nasional non-alam dengan memperhatikan isi Undang-Undang No. 24 Tahun 2007 tentang Penanggulangan Bencana.

Percepatan penanganan virus Covid-19 ini harus dilakukan dengan tepat, cepat, fokus, terpadu dan bersinergi di antara kementerian/lembaga dan pemerintah daerah. Sehingga dikeluarkanlah Keputusan Presiden (Keppres) No. 7 tahun 2020 tentang Gugus Tugas Percepatan Penanganan Corona Virus Disease 2019 (Covid-19). Menurut Pasal 11 Keppres ini menyatakan bahwa Gubernur dan Bupati/Wali kota membentuk Gugus Tugas Percepatan Penanganan Covid-19 Daerah berdasarkan pertimbangan dan rekomendasi Ketua Pelaksana Gugus Tugas Percepatan Penanganan Covid-19. Penanganan Covid-19 di daerah dilakukan dengan memperhatikan arahan Gubernur yang merupakan Ketua Pelaksana Gugus Tugas Percepatan Penanganan Covid-19.

\section{Permasalahan}

Pandemi korona (Covid-19) menimbulkan dampak yang besar bagi kesehatan dan ekonomi masyarakat. Penyebaran Covid-19 di berbagai daerah semakin sulit dibendung, termasuk di Jawa Tengah. Pada minggu ketiga bulan April 2020, kasus positif korona di Jawa Tengah merupakan tertinggi kedua di Indonesia (jateng.inews.id/23 April 2020). Hampir semua kabupaten/kota di Jawa Tengah terpapar Covid-19.

Dampak kesehatan yang dikutip dari corona.jatengprov.go.id, media lokal (www.idntimes.com) menyatakan jumlah orang dalam pemantauan (ODP) terus meningkat. Pada 10 April tercatat 19.543 orang. Sedangkan kasus positif mencapai 144 kasus. Dari jumlah tersebut, 104 masih dirawat, 18 orang sembuh dan 22 orang meninggal. Pada periode tersebut, terdapat 20 kabupaten/kota dinyatakan zona merah Covid-19. Situasi ini membutuhkan intervensi pemerintah daerah yang selaras dengan kebijakan nasional.

Pemerintah Provinsi Jawa Tengah membuat suatu langkah percepatan penanganan Covid-19 yang terstruktur, sistematis, serta menyeluruh dengan melibatkan masyarakat dalam pelaksanaannya dengan pembentukan Satgas Jogo Tonggo. Kebijakan ini merupakan suatu keputusan politik pemerintah Pemerintah Provinsi Jawa Tengah dalam rangka melindungi keselamatan warga masyarakat dari efek masif Covid-19. Gubernur Jawa Tengah selaku ketua Gugus Tugas percepatan penanganan Covid-19 di Provinsi Jawa Tengah menuangkan kebijakan tersebut dalam Instruksi Gubernur Jawa Tengah No. 1 Tahun 2020 tentang Pemberdayaan Masyarakat dalam Percepatan penanganan Covid-19 di Tingkat Rukun Warga (RW) Melalui Pembentukan "Satgas Jogo Tonggo" untuk mengatasi meluasnya wabah virus corona.

Secara garis besar kebijakan diartikan sebagai public policy, istilah kebijaksanaan atau kebijakan berasal dari kata policy yang berkaitan dengan pengambilan kebijakan pemerintah. Dengan demikian, pemerintah berwenang dalam mengatur masyarakat dan melayani perihal kepentingan umum.

Menurut Anderson dalam Syafri dan Setyoko (2016: 12) kebijakan memiliki makna bahwa:

1. Kebijakan mengarah pada suatu maksud tertentu sehingga kegiatan tersebut memiliki orientasi terhadap tujuan;

2. Kebijakan berkaitan dengan perbuatanperbuatan atau pola perbuatan dilakukan pejabat pemerintah; 
3. Kebijakan berupa sesuatu yang dikerjakan pemerintah, bukanlah hal yang ingin atau direncanakan oleh pemerintah;

4. Kebijakan dapat berbentuk positif yaitu tindakan nyata pemerintah dalam mengatasi masalah, ataupun bersifat negatif pemerintah tidak mengambil suatu keputusan apa pun;

5. Kebijakan harus berdasarkan peraturan yang bersifat memaksa, sehingga elemen masyarakat harus mematuhinya.

Berdasarkan pengertian tersebut kebijakan pemerintah merupakan suatu hal yang dilakukan pemerintah berdasarkan aturan yang ada untuk mengatasi suatu permasalahan dalam hal ini adalah adanya pandemi Covid-19 yang wajib ditaati oleh seluruh elemen masyarakat. Tidak semua isu yang beredar di masyarakat dapat dimaksudkan dalam agenda pemerintah untuk diproses menjadi suatu kebijakan. menurut Rianto Nugroho (2004) dalam Herabudin (2016: 39) isu yang termasuk dalam agenda kebijakan memiliki latar belakang yang kuat berkaitan dengan analisis kebijakan dan terkait dengan enam pertimbangan berikut.

1. Mencapai tingkat kritis sehingga tidak bisa diabaikan;

a. Sensitive, yaitu cepat menarik perhatian masyarakat;

b. Menyangkut aspek tertentu dalam masyarakat;

c. Menyangkut banyak pihak sehingga mempunyai dampak yang luas dalam masyarakat jika diabaikan;

d. Berkaitan dengan kekuasaan dan legitimasi;

e. Berkaitan dengan kecenderungan yang sedang berkembang dalam masyarakat.

Suatu kebijakan yang telah ditetapkan oleh pemerintah harus diimplementasikan dengan baik. Implementasi kebijakan memberikan subjek yang penting dalam rangkaian peristiwa kebijakan. Bahkan dijelaskan oleh seorang pakar kebijakan asal Afrika, Udoji dalam Wahab (2012: 126), "Pelaksanaan kebijakan merupakan kegiatan penting. Bahkan dapat dikatakan lebih penting dari suatu pembuat kebijakan". Kebijakan hanyalah angan-angan belaka dan tersimpan rapat dan menjadi arsip bila tidak diterapkan di lapangan.

Implementasi kebijakan tidak hanya dipengaruhi oleh para pelaksana kebijakan namun juga oleh masyarakat yang merupakan sasaran dari kebijakan ini. Diperlukan kerja sama dengan masyarakat sehingga menumbuhkan kesadaran Masyarakat dalam menyikapi Covid-19 ini sesuai dengan protokol kesehatan yang saat ini masih belum sepenuhnya dapat berjalan dengan baik.

\section{Penelitian Terdahulu}

Penelitian ini terinspirasi oleh beberapa penelitian terdahulu, yang membahas bagaimana Kebijakan Jogo Tonggo ini dilaksanakan di tengah adanya pandemic Covid-19. Penelitian Erisandi Erditama dan Puji Lestari yang berjudul Jogo Tonggo: Membangkitkan Kesadaran Dan Ketaatan Warga Berbasis Kearifan Lokal Pada Masa Pandemi Covid-19 Di Jawa Tengah (Eridandi \& Puji, 2020) menemukan bahwa Jogo Tonggo dalam masa darurat Covid-19 mendorong terbentuknya kesadaran bersama dan ketaatan warga masyarakat Jawa Tengah pada imbauan negara. Ketaatan masyarakat didorong oleh; pilihan taat karena ancaman pandemi, menguatnya solidaritas sosial dan nilai-nilai kemanusiaan, kebersamaan dalam masyarakat pada tingkat RT dan RW, selain adanya aturan hukum yang mengandung sanksi. Selain itu, penelitian ini menemukan tentang pentingnya membangkitkan kesadaran warga untuk taat pada protokol kesehatan menghadapi penyebaran Covid-19 melalui modal sosial yang 
berupa jaring sosial di dalam masyarakat. Selanjutnya penelitian yang dilakukan oleh Kurnia Sulistiani dan Kaslam yang berjudul Kebijakan Jogo Tonggo Pemerintah Provinsi Jawa Tengah dalam Penanganan Pandemi Covid-19 (Kurnia \& Kasam, 2020) dengan hasil penelitian menunjukkan bahwa pemerintah Jawa Tengah telah mengeluarkan kebijakan Jogo Tonggo dalam menangani wabah Covid-19, namun faktanya hingga saat ini permasalahan belum terselesaikan dengan baik. Salah satu faktor penyebabnya adalah kurangnya kesadaran masyarakat terhadap bahaya wabah Covid-19, sehingga dibutuhkan beberapa tindakan seperti peningkatan kualitas anggota Jogo Tonggo, adanya evaluasi dan pemilihan media sosial.

\section{Pernyataan Kebaruan Ilmiah}

Penulis melakukan penelitian yang berbeda dan belum dilakukan oleh penelitian terdahulu, di mana konteks penelitian yang dilakukan, yakni menggunakan pendapat Edward III dalam Indiahono (2017: 33) yang menyatakan bahwa implementasi kebijakan dipengaruhi oleh komunikasi, sumber daya, disposisi dan struktur birokrasi.

\section{Tujuan}

Penelitian ini bertujuan untuk menganalisis dan memperoleh gambaran yang jelas mengenai implementasi kebijakan Jogo Tonggo di Kecamatan Simo Kabupaten Boyolali Provinsi Jawa Tengah, faktor pendukung dan penghambat, serta upaya yang dilakukan untuk mengatasi faktor penghambat tersebut.

\section{METODE PENELITIAN}

Penelitian ini menggunakan metode kualitatif yang bersifat deskriptif dengan pendekatan induktif. Di mana penulis telah mengetahui terlebih dahulu adanya permasalahan yang ada di Lapangan kemudian mengaitkannya dengan teori yang ada dan kemudian mencari solusi atau rekomendasi dari permasalahan yang ada sesuai dengan tujuan dilaksanakannya penelitian ini.

Menurut Sugiyono (2019: 287) "di dalam penelitian kualitatif, peneliti masuk ke dalam keadaan sosial tertentu, dilakukan kegiatan observasi dan wawancara terhadap orang yang dianggap mengetahui keadaan sosial yang diteliti". Dalam pengumpulan data penulis menggunakan tiga teknik pengumpulan data yaitu wawancara, observasi, dokumentasi, triangulasi yang diperoleh dari berbagai sumber berupa penelusuran berita di televisi, media online, media sosial, serta dokumen yang ada di lokasi tempat dilaksanakan penelitian.

Wawancara dilakukan secara langsung kepada pihak-pihak yang dianggap mengetahui pelaksanaan kebijakan Jogo Tonggo ini atau biasa disebut purposive sampling. Observasi dilakukan secara langsung pada kehidupan masyarakat di lokasi penelitian dengan cara memotret fenomena yang terjadi pada masa pandemi terutama saat penulis melaksanakan penelitian. Untuk melakukan analisis data penulis menggunakan cara reduksi data, penyajian data, dan simpulan.

Penelitian ini dilaksanakan di Kantor Kecamatan Simo, Kabupaten Boyolali, Provinsi Jawa Tengah dengan sampel tiga desa yaitu Desa Pelem, Desa Gunung, dan Desa Teter. Waktu pelaksanaan adalah 4 Januari-2 Februari 2021.

\section{HASIL DAN PEMBAHASAN}

\section{Implementasi Kebijakan Jogo Tonggo}

Konsep Jogo Tonggo merupakan suatu gerakan percepatan penanganan bencana non-alam Covid-19yang berbasis masyarakat yang dilakukan di Jawa Tengah. Jogo merupakan frase bahasa Jawa yang berarti jaga atau menjaga dan tonggo yang berarti tetangga. Dengan demikian, Jogo Tonggo 
dalam bahasa Jawa artinya taga tetangga atau saling menjaga tetangga. Program Jogo Toggo yang diinisiasi Pemerintah Provinsi Jateng merupakan program pelibatan masyarakat selaku garda terdepan dalam melawan Covid-19 di desa. Secara organisatoris (berdasarkan buku Saku Satgas Jogo Tonggo), program ini dijalankan Satgas Jogo Tonggo. Dalam logika keilmuan, program semacam ini dapat dilihat sebagai cara bijak memanfaatkan kearifan lokal masyarakat Jateng yang masih menjunjung tinggi nilai solidaritas, kegotongroyongan. Nilai-nilai semacam ini strategis dalam menghadapi sifat/karakteristik pandemi Covid-19 yang tidak menentu, berbahaya serta mempunyai daya sebar secara eksponensial (1 orang bisa menularkan ke sekian banyak orang secara berantai).

Cara-cara kerja sporadik yg dijalankan di daerah lain di Indonesia tidak menggunakan pendekatan seperti Jogo Tonggo. Sehingga polanya pun tidak taktikal. Pasif dan hampir mirip pemadam kebakaran yang cara kerjanya bila ada kasus baru gerak. Masyarakat dijadikan objek, bukan subjek yang berkepentingan langsung dan di sini lah nilai plus Jogo Tonggo. Masyarakat melawan pandemi korona/pagebluk yang tidak nyata, dan baru terlihat setelah ada korban, tidak bisa secara spontan alias dadakan. Oleh karena itu, Perlu pendekatan preventif dan promotif untuk mengatasinya serta menempatkan masyarakat sebagai garda terdepan dan bersama pemerintah melawan penyebaran serta dampak adanya virus Covid-19.

Berdasarkan lampiran I Instruksi Gubernur Jawa Tengah No. 1 Tahun 2020 tentang Pemberdayaan Masyarakat dalam Percepatan penanganan Covid-19 di Tingkat Rukun Warga (RW) Melalui Pembentukan "Satgas Jogo Tonggo" mempunyai Struktur Organisasi yaitu Satgas Jogo Tonggo dipimpin

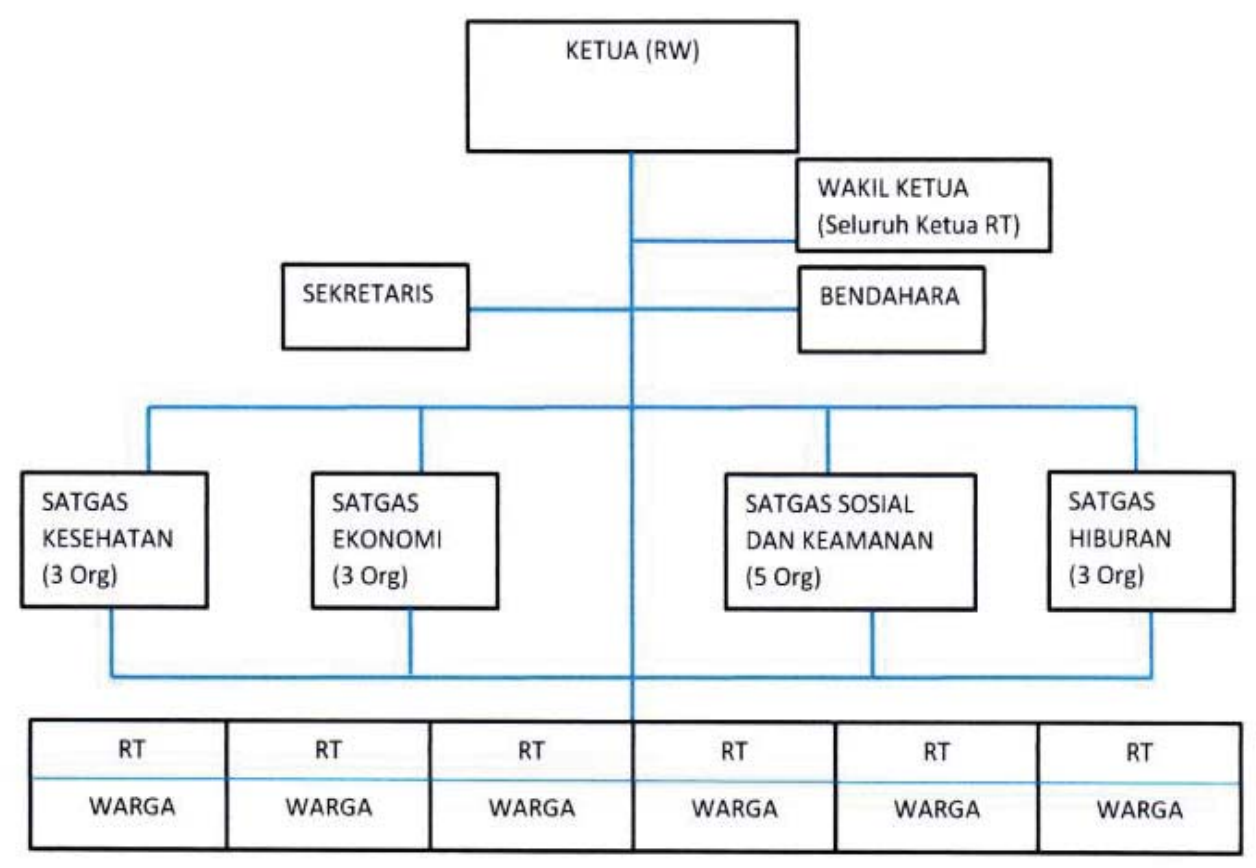

Gambar 1

Struktur Organisasi "Satgas Jogo Tonggo"

Sumber: Lampiran I Instruksi Gubernur Jawa Tengah No. 1 Tahun 2020 tentang Pemberdayaan Masyarakat dalam Percepatan penanganan Covid-19 Di Tingkat Rukun Warga (RW) Melalui Pembentukan "Satgas Jogo Tonggo" 
oleh Ketua RW dan wakilnya adalah semua Ketua RT di wilayah RW tersebut, serta dibantu oleh seorang Bendahara dan seorang Sekretaris sebagaimana tampak pada bagan Struktur Organisasi Satgas Jogo Tonggo (Gambar 1).

Kebijakan Jogo Tonggo, mempunyai 10 bidang struktur anggota untuk membantu pemerintah dalam menangani Covid-19. 10 bidang tersebut yaitu Anggota Karang Taruna, Dasa Wisma, Posyandu, Pendamping PKH, PPL (Pertanian), Pendamping Desa, Organisasi masyarakat Lainnya, masyarakat, Bidan Desa, dan Linmas. Saat ini Kebijakan Jogo tonggo telah dilaksanakan oleh seluruh Kabupaten/ Kota di Provinsi Jawa Tengah.

Implementasi kebijakan Jogo Tonggo di Kecamatan Simo Kabupaten Boyolali Provinsi Jawa Tengah sudah berjalan baik sesuai dengan pedoman yang ada meskipun terdapat beberapa kendala. Dikaitkan dengan teori implementasi Edward III yang terdiri dari empat dimensi dapat disimpulkan sebagai berikut.

\section{- Komunikasi}

Komunikasi telah dilakukan oleh pemerintah Kecamatan Simo, Desa Pelem, Desa Gunung dan Desa Teter, beserta seluruh anggota Satgas Jogo Tonggo melalui kegiatan sosialisasi, pamflet, rapat dengan perwakilan masyarakat, pengumuman di tempat ibadah, dan melalui media komunikasi lainnya seperti WA, Telp, SMS. Komunikasi tersebut dilakukan untuk memberikan kejelasan terkait adanya kebijakan ini sehingga tujuan dan sasaran dari kebijakan ini tepat dan sesuai. Konsistensi merupakan hal yang penting dalam implementasi kebijakan, terlihat dengan keikutsertaan Satgas Jogo Tonggo di berbagai acara yang melibatkan masyarakat. Namun demikian, masih ada masyarakat yang belum mengetahui adanya kebijakan ini.

\section{- Sumber Daya}

Sumber daya dalam pelaksanaan kebijakan Jogo Tonggo ini terdiri dari sumber daya manusia, sumber daya finansial, dan fasilitas. Sumber daya manusia yang melaksanakan kebijakan ini merupakan tim yang dibuat dari berbagai latar belakang pekerjaan yang berbeda, sehingga mengalami kesulitan untuk melaksanakan kebijakan. Selain itu, lingkungan yang kecil membuat unsur pelaksana tidak dapat terpenuhi semuanya. Satgas Jogo Tonggo dilakukan oleh warga yang bersedia dan mampu untuk melaksanakan kebijakan ini secara suka rela.

Sumberdayafinansialdalampelaksanaan kebijakan ini berasal dari APBN, APBD, dan APBDes yang telah mengalami perubahan untuk penanganan Covid-19 serta berasal dari swadaya masyarakat dan bantuan pihak ketiga. Sumber daya finansial sudah cukup memadai sehingga warga yang terdampak dalam hal ini melakukan isolasi mandiri tetap dapat memenuhi kebutuhannya.

Fasilitas yang digunakan merupakan menggunakan sarana dan prasarana yang sudah ada sebelumnya dan merupakan bantuan dari berbagai pihak. Fasilitas yang sudah ada cukup baik untuk melaksanakan kebijakan ini. Meskipun demikian, ada beberapa fasilitas yang sudah tidak digunakan lagi seperti tepat karantina. Hal tersebut karena masyarakat saat ini lebih memilih melakukan isolasi mandiri di rumah masing-masing. Serta pos keamanan di pintu masuk RW 01 Desa Teter saat ini sudah tidak dijaga dengan ketat lagi dan hanya berfungsi saat adanya ronda di malam hari.

\section{- Disposisi}

Dalam pelaksanaan kebijakan Jogo Tonggo, setiap sumber daya yang ada sudah memiliki tanggung jawab masing-masing, terlepas dari segala keterbatasan yang ada para pelaksana kebijakan berusaha untuk memenuhi tanggung jawab itu. Demikian 
pula bentuk semangat kerja sama dan ikhlas dalam melaksanakan kebijakan ini.

\section{- Struktur Birokrasi}

Pelaksanaan kebijakan Jogo Tonggo telah sesuai dengan prosedur, semua pertanggungjawaban berbentuk dokumen laporan ada di tingkat RW dan Satgas tingkat desa, terdapat juga laporan yang jelas sesuai dengan SOP yang ada. Namun kenyataannya ada warga yang tidak mematuhi SOP tersebut dengan tidak melaporkan bahwa dirinya positif Covid-19. Mengingat kebijakan Jogo Tonggo ini merupakan kebijakan yang ada di tingkat RW kerja sama dengan Satgas di atasnya maupun dengan masyarakat. Untuk melaksanakan kebijakan ini koordinasi telah dilakukan oleh para implementor kebijakan secara tatap muka maupun melalui media lain seperti grup WA, SMS, Telpon atau media lainnya.

\section{Faktor Pendukung dan Penghambat}

Pemerintah Kecamatan Simo sangat mendukung adanya Satgas Covid-19 khususnya Kebijakan Jogo Tonggo. Hal ini dapat dilihat dari observasi secara langsung yang dilakukan oleh penulis dan juga informasi yang didapatkan oleh penulis melalui wawancara kepada beberapa responden bahwa Satgas Jogo Tonggo merupakan suatu komitmen bersama warga dalam menangani percepatan penanggulangan penyebaran virus corona yang terjadi saat ini. hal tersebut dilakukan untuk menciptakan kondisi yang kondusif bagi seluruh masyarakat sehingga dampak adanya pandemi Covid-19 ini dapat diatasi dengan baik.

Faktor pendukung kebijakan ini adalah budaya gotong royong, kepedulian dan kebersamaan yang masih kental di masyarakat, serta koordinasi yang jelas antar implementor kebijakan sehingga dapat dilakukan tindakan yang tepat kepada masyarakat yang terkena dampak Covid-19. Faktor penghambat pelaksanaan kebijakan ini yaitu masih adanya warga yang belum memahami kebijakan Jogo Tonggo, dan kesadaran masyarakat terhadap protokol kesehatan masih rendah.

Berikut ini merupakan data pelanggaran hasil penegakan protokol kesehatan yang dilakukan oleh Satgas Covid-19 di Kecamatan Simo pada saat dilaksanakan PPKM Jawa dan Bali pada 11 Januari 2021-25 Januari 2021:

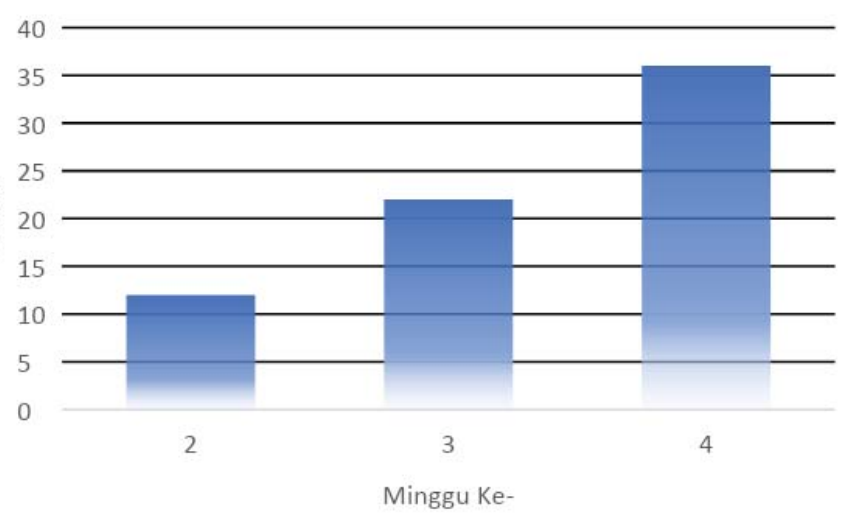

Gambar 2

Data Pelanggaran Hasil Penegakan Prokes Covid-19 di Kecamatan Simo (Januari 2021)

Sumber: Dokumen Satgas Covid-19 Kecamatan Simo 2021

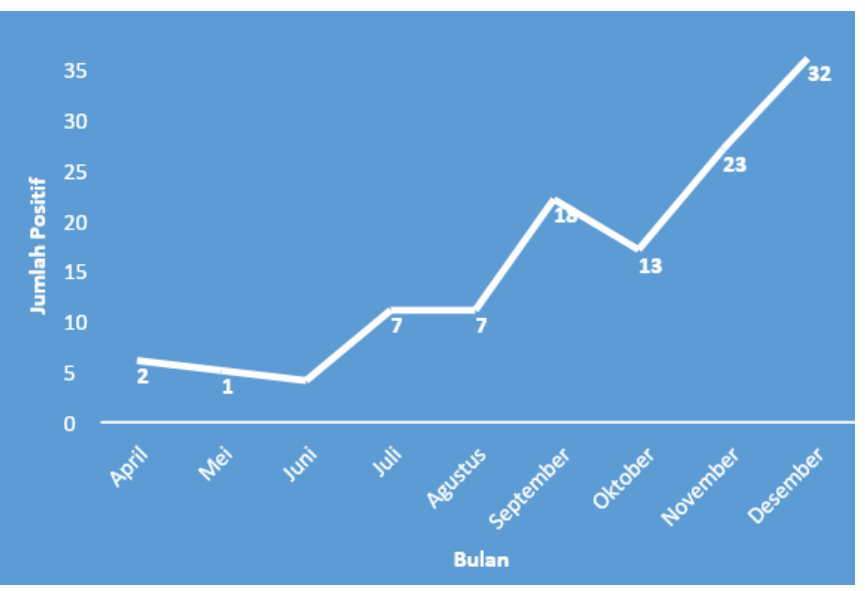

Gambar 3

Data Kasus Positif Covid-19 di Kecamatan Simo (April-Desember 2020)

Sumber: Data Covid-19 Puskesmas Simo 2020

Berdasarkan data Gambar 2 dapat dilihat bahwa angka pelanggaran masyarakat terhadap protokol kesehatan masih terus meningkat yang menunjukkan bahwa tingkat kesadaran masyarakat untuk melaksanakan 
protokol kesehatan masih rendah. Hal tersebut membuat masih banyaknya angka positif Covid-19 di Kecamatan Simo. Berikut merupakan rekapitulasi kasus Covid-19 di Kecamatan Simo dari April hingga Desember 2020 tampak pada Gambar 3.

\section{Upaya untuk Mengatasi Faktor Penghambat}

Pelaksanaan Kebijakan Jogo Tonggo di Kecamatan Simo yang dilakukan oleh Satgas Covid-19 di tingkat RW tidak terlepas dari berbagai faktor yang berpotensi menghambat pencapaian kinerja seperti yang telah diuraikan di atas. Oleh karena itu, baik pemerintah Kecamatan Simo maupun pihak-pihak yang terlibat dalam pelaksanaan Kebijakan Jogo Tonggo melakukan berbagai upaya dalam mengatasi permasalahan yang terjadi di lapangan. Upaya yang dilakukan untuk mengatasi faktor penghambat Implementasikan Kebijakan Jogo Tonggo di Kecamatan Simo Kabupaten Boyolali Provinsi Jawa Tengah yaitu dengan melakukan sosialisasi, memberikan contoh kepada masyarakat, dan melakukan contact tracking.

\section{Diskusi Temuan Utama Penelitian}

Program Jogo Toggo yang diinisiasi Pemerintah Provinsi Jateng merupakan program pelibatan masyarakat selaku garda terdepan dalam melawan Covid-19 di desa. Secara organisatoris (berdasarkan buku Saku Satgas Jogo Tonggo), program ini dijalankan Satgas Jogo Tonggo. Dalam logika keilmuan, program semacam ini dapat dilihat sebagai cara bijak memanfaatkan kearifan lokal masyarakat Jateng yang masih menjunjung tinggi nilai solidaritas, kegotongroyongan. Nilai-nilai semacam ini strategis dalam menghadapi sifat/karakteristik pandemi Covid-19 yang tidak menentu, berbahaya serta mempunyai daya sebar secara eksponensial (1 orang bisa menularkan ke sekian banyak orang secara berantai).
Cara-cara kerja sporadik yg dijalankan di daerah lain di Indonesia tidak menggunakan pendekatan seperti Jogo Tonggo. Sehingga polanya pun tidak taktikal. Pasif dan hampir mirip pemadam kebakaran yang cara kerjanya bila ada kasus baru gerak. Masyarakat dijadikan objek, bukan subjek yang berkepentingan langsung dan di sini lah nilai plus Jogo Tonggo. Masyarakat melawan pandemi korona/pagebluk yang tidak nyata, dan baru terlihat setelah ada korban, tidak bisa secara spontan alias dadakan. Oleh karena itu, Perlu pendekatan preventif dan promotif untuk mengatasinya serta menempatkan masyarakat sebagai garda terdepan dan bersama pemerintah melawan penyebaran serta dampak adanya virus Covid-19.

Layaknya program lain, kebijakan Jogo Tonggo juga masih memiliki beberapa kekurangan di antaranya fakta di lapangan menunjukkan bahwa pemerintah telah mengeluarkan kebijakan sebagai sikap untuk penanganan wabah Covid-19 di Jawa Tengah. Seperti kebijakan Jogo Tonggo, yang melibatkan banyak elemen lembaga, organisasi, instansi, dan masyarkat itu sendiri. Kedua, pelaksanaan kebijakan Jogo Tonggo belum maksimal. Terlihat, masih banyak masyarakat yang kurang sadar akan bahwa Covid-19, masih banyak yang menghiraukan himbauan pemerintah, seperti stay at home, layaknya temuan Kurnia Sulistiani dan Kaslam yang berjudul Kebijakan Jogo Tonggo Pemerintah Provinsi Jawa Tengah dalam Penanganan Pandemi Covid-19 (Kurnia \& Kasam, 2020).

\section{SIMPULAN}

Implementasi kebijakan Jogo Tonggo di Kecamatan Simo Kabupaten Boyolali Provinsi Jawa Tengah sudah berjalan baik sesuai dengan pedoman yang ada meskipun terdapat beberapa kendala di dalamnya yaitu masyarakat yang belum mengetahui adanya kebijakan ini, pelaksana kebijakan berasal 
dari berbagai latar belakang pekerjaan sehingga tidak menjalankan tugasnya secara optimal, fasilitas yang sudah ada tidak digunakan dengan maksimal, dan juga warga yang tidak mematuhi SOP yang ada.

Faktor pendukung kebijakan ini adalah budaya gotong royong, kepedulian dan kebersamaan yang masih kental di masyarakat, serta koordinasi yang jelas antar implementor kebijakan sehingga dapat dilakukan tindakan yang tepat kepada masyarakat yang terkena dampak Covid-19. Faktor penghambat pelaksanaan kebijakan ini yaitu masih adanya warga yang belum memahami kebijakan Jogo Tonggo, dan kesadaran masyarakat terhadap protokol kesehatan masih rendah.

\section{SARAN}

Upaya yang dilakukan untuk mengatasi faktor penghambat Implementasikan Kebijakan Jogo Tonggo di Kecamatan Simo Kabupaten Boyolali Provinsi Jawa Tengah yaitu dengan melakukan sosialisasi, memberikan contoh kepada masyarakat, dan melakukan contact tracking.

\section{DAFTAR RUJUKAN}

Herabudin. 2016. Studi kebijakan Pemerintah (Dari Filosofi ke Implementasi. Bandung: Pusaka Setia.

Sugiyono. 2019. Metode Penelitian Kuantitatif Kualitatif dan R\&D. Bandung: Alfabeta.

Syafri, Wirman dan P. Israwan Setyoko. 2010. Implementasi Kebijakan Publik dan Etika Profesi Pamong Praja. Sumedang: Alqa Prisma Interpelita.

Wahab, Solichin Abdul. 2012. Analisis Kebijakan (dari Formulasi ke Penyusunan ModelModel Implementasi Kebijakan Publik). Jakarta: Bumi Aksara.

\section{Peraturan Perundang-Undangan}

Undang-Undang No. 24 Tahun 2007 tentang Penanggulangan Bencana.

Keputusan Presiden (Keppres) No. 11 Tahun 2020 tentang Penetapan Kedaruratan Kesehatan Masyarakat corona virus disease 2019 (Covid-19).

Keputusan Presiden (Keppres) No. 7 tahun 2020 tentang Gugus Tugas Percepatan Penanganan Corona Virus Disease 2019 (Covid-19).

Instruksi Gubernur Jawa Tengah No. 1 Tahun 2020 tentang Pemberdayaan Masyarakat dalam Percepatan penanganan Covid-19 Di Tingkat Rukun Warga (RW) Melalui Pembentukan "Satgas Jogo Tonggo".

\section{Website}

Erisandi Arditama dan Puji Lestari. Jurnal Politik dan Kewarganegaraan, Fakultas Ilmu Sosial Universitas Negeri Semarang, Jogo Tonggo: Membangkitkan Kesadaran Dan Ketaatan Warga Berbasis Kearifan Lokal Pada Masa Pandemi Covid-19 Di Jawa Tengah. Vol. 8 No. 2 (Mei, 2020) https:// e-journal.undiksha.ac.id/index.php/JJPP [16 September 2020]

20 Daerah di Jawa Tengah Masuk Zona Merah Covid-19! www.Idntimes.com. https:// www.idntimes.com/news/indonesia/ dhana-kencana-1/daerah-di-jawatengah-zona-merah-virus-coronanasional/full [29 September 2020]

Tertinggi Kedua di Indonesia, Positif Corona di Jateng Melonjak 538 Kasus. Jateng inews. https://jateng.inews.id/berita/ tertinggi-kedua-di-indonesia-positifcorona-di-jateng-melonjak-538-kasus [29 September 2020] 